\title{
Product Elimination: The Nigerian Insurance Industry Experience
}

\author{
Ben E. Akpoyomare Oghojafor \\ Department of Business Administration \\ Faculty of Business Administration, University of Lagos, Nigeria \\ Tel: +234-803-300-0522Ｅ-mail akpoyomareo@yahoo.co.uk \\ Sunday Adekunle Aduloju (Corresponding Author) \\ Department of Actuarial Science and Insurance \\ Faculty of Business Administration, University of Lagos, Nigeria \\ Tel: +234-802-341-5056_E-mail ksaduloju@yahoo.co.uk \\ Folake Feyisayo Olowokudejo \\ Department of Actuarial Science and Insurance \\ Faculty of Business Administration, University of Lagos \\ Tel:+234-806-270-4956Ｅ-mail: kudejomrs@yahoo.com
}

Received: September 6, 2011

Accepted: January 5, 2012 Published: March 15, 2012

doi:10.5430/ijba.v3n2p74

URL: http://dx.doi.org/10.5430/ijba.v3n2p74

\begin{abstract}
There is a growing interest in the way products are eliminated in order to prevent purchase discontinuity. The authors present an empirical study on the ways products are eliminated in the Nigerian insurance industry. Specifically, the papers examined the factors normally considered before elimination decisions are taken, and the key problems encountered during elimination stages. The data obtained from thirty-four insurance companies through a structured questionnaire were analyzed and a ranking of the variables relevant to the elimination process was provided. The kolmogorov-smirnov test was used to test the formulated hypotheses. Government policies and regulations as well as operational problems are the most important factors leading to elimination process. The paper also reports that the most difficult problem encountered during the elimination process is maintaining customer's goodwill.
\end{abstract}

Keywords: Product Elimination, Insurance Products, Financial Services

\section{Introduction}

In what ranks to be one of the earliest works on product elimination, the study by Alexander (1964) reveals that product deletion is an uninspiring and depressing process. According to that study, putting products to death, or letting them die is a drab business, and often engenders much of the sadness of a final parting with old and tried friends. No wonder, while many researchers and practitioners have focused attention on major considerations for the research and development or the introductory stage of product life cycle, the development of product elimination theory has received minimal attention (Banville and Fletcher, 1974). As the literature on new product and service development grows at an impressive rate, research on product elimination remains remarkably limited. In addition, the available literature on product elimination reveals a manufacturing orientation (Argouslidis and Baltas, 2007).

Despite the paucity of research based contributions to the understanding of the product elimination process (Gounaris, Avlonitis and Papastathopoulou, 2006), Alexander (1964) argues that in a changing market, product deletion is as vital as addition of new products. Product elimination is an integral part of a company's innovation process, and plays a significant role in determining the overall profitability of an individual company. Although, much limited in comparison with that of manufacturing sector, there is a growing body of literature on product elimination in financial institutions (Harness, 2004; Harness and Harness, 2000; and Argouslidis and Baltas, 2007). A study in the UK retail financial service sector reveals how product elimination can be handled without creating customer purchasing discontinuity 
(Harness and Harness, 2000). In Nigeria, factual knowledge in such an important area of product management as this is limited. And to the best of our knowledge, no known work has been carried out in this country on product elimination in the insurance industry. The purpose of the current research is to study the procedure of product elimination in the Nigerian insurance industry.

The rest of the paper is structured as follows: overview of the Nigerian insurance industry, a review of the literature, research methodology, discussion and conclusion.

\section{Overview of the Nigerian Insurance Industry}

The 2009 Insurance Industry Report by Agusto \& Co shows that Nigeria has one of the lowest levels of insurance patronage in the world, which is put at as some $2 \%$ (Daily Trust, 2009). The gross premium income (GPI) in relation to the gross domestic product (GDP) as at 2004 was $0.98 \%$ as against $14.38 \%$ in South Africa. In addition, life insurance premium per capita stood at $\$ 0.7$ as against $\$ 545$ in South Africa, and non life insurance premium per capita stood at $\$ 3.3$ as against $\$ 141$ in South Africa. This clearly reveals the level of underdevelopment of the Nigerian insurance market (Nigeria Investments.com, 2009).

The year 2008 was quite remarkable in the history of the Nigerian insurance industry, as the first year of the post-consolidation exercise which produced 49 insurance companies and 2 reinsurance companies, with a total market capitalization of over N600billion (Barbington-Ashaye, 2009). This report calls on the insurers to translate not only the customers' needs into product and service requirements but also to deliver the products at competitive rates with the right quality. It also emphasizes the importance of product features and strategy, which will involve significant level of innovations in order to meet changing customers' needs.

In most cases, the insurers in the country take actions to terminate policies of certain insureds in the event of unfavourable claims experience rather than eliminate a particular product. For example, between 2002 and 2007 the Nigerian insurance industry lost N75.8 billion on the Nigeria National Petroleum Corporation group insurance account alone. Subsequently, many of the participating insurers were no longer willing to continue as the level of risk exposure for oil workers appears to be increasing by the day due to the activities of the kidnappers in the Niger Delta area in the country (Ghana Business News, 2009). While the issue of product elimination is virtually given no attention, often, discussions among the practitioners normally revolve around marketing of insurance products (Okehi, 2007; Chilekezi, 2006).

Perhaps due to its nature, insurance product is subject to regulations all over the world. In India, development of insurance products is governed by three tier model: regulation of the product design, regulation of the product pricing, and regulation of the product marketing. For example, Rule 2 of the IRDA (Protection of Policyholders Interests) Regulation 2002, gives the IRDA power to instruct insurance companies to either withdrawal a product or suspend the marketing of the product till the defects found in the products are rectified, if such a product is found to be detrimental to the interest of the policyholders (Veena, 2009).

\section{Literature Review}

In making decision for its product mix, a company will consider series of questions that will enable it identify where its existing strengths and weaknesses lie. One of such questions is: Is anyone product so invaluable to the company in terms of reputation that its deletion will harm the product line or the product mix? (Adeleye, 2003). To this end, many companies are not leaving to chance the issue of product portfolio analysis, the main objective of which is to maintain an adequate cash flow within the company and direct such to the areas of greatest marketing opportunity (Assael, 1985).

Product elimination formerly was perceived as a negative activity concerned with removing products that no longer add to the objectives of an organisation, and no longer meet the need of the customer (Harness and Harness, 2000). This may lead to a discontinuity that can negatively affect the purchasing relationship and ultimately lead to customers exiting the organisation (Stewart, 1998). Although, while not much has been written on product deletion compared with other aspects of product management, over the years, questions relating to why products should be deleted, which products should be deleted, and when products should be deleted have caused managers numerous headaches (Eckles, 1971). On why products should be deleted, this author states that weak products tend to consume a disproportionate share of a manager's time, tie up production on short runs, and generally require more attention than healthy products.

Going through the works of some earlier researchers (such as Rothe, 1970; Eckles 1971; Hise and McGinnis, 1975; Avlonitis, 1983; Avlonitis, 1985; Hart, 1988; Avlonitis, 1990 Avlonitis, 1993; and Vyas, 1993), Mitchell, Taylor and Tanyel (1995) state that the body of research on elimination decision can be divided into two groups: (1) normative works, replete with checklists and sequential actions to guide the decision-maker, and (2) empirical works, which focus on specific components of the decision-making process. Regarding the first group, Hart (1988) made reference to some 
empirical research that has repudiated the earlier normative assumption that all decisions to drop a product from the range are based on unsatisfactory sales and profits. The author concludes that not all weak products or mature products are suitable for withdrawal, and not all withdrawal candidates are weak or mature products. From this body of research, products may be deleted for a number of reasons. Salerno (1983) finds out that a product may be deleted, either due to factors inherent in the product, or through external stimuli, such as the development of a new product. The study of Banville and Pletcher (1974) indicates that profitability and financial variables are most significant in the elimination decision process.

The work of Varadarajan, Defanti, and Busch (2006) focuses on the organizational and environmental drivers of brand deletion propensity. They find out that brand deletion can be critical from the standpoint of a firm being able to free up resources to redeploy toward enhancing the competitive standing and financial performance of brands in its portfolio with the greatest potential to positively affect its image and reputation. Product elimination needs to be planned carefully to prevent damage to the company's image. While some products can be eliminated immediately, others may have to be withdrawn over a period of time so that customers will have time to adjust to the replacement. The company may continue to provide service for a discontinued product for a certain period of time to retain customer's goodwill (Marketing Education Resource Center, 2009).

In a recent study of product discontinuation, Argouslidis (2007) provides service practitioners evidence about the factors that financial institutions consider in order to evaluate the impact on the entire company of an eventual decision to eliminate a financial service from the range; the degree of influence that these factors exert on management; and the contextual conditions that shape the above degree of influence. The study is interesting because a decade earlier, points were made that recognition of customer value drivers was important in relationship marketing. One must also bear in mind the significance of considering the market conditions in which the product or service proposed for elimination is competing, the possibilities for efficiently reallocating the company's resources should the service is eventually eliminated and also the related cost. For example, when Intel refused to address customers concerns, the customer rebellion forced Intel into a product recall that cost the company over $\$ 500$ million and its relationships with the customers (Harmon and Laird, 1997).

Mowen (1987) describes customer value drivers as the decision related attributes that are perceived by the customer to be the most important to the choice process. In a study of product elimination practice in retail banks, building societies and retail insurance organizations, issues that act as key drivers of product elimination are product, strategy, customer, cost, information technology, operation, personnel, and external forces. Effective product elimination requires that organisations are able to identify drivers and be willing to act upon them (Harness, 2003).

From the empirical research, product recalls can adversely affect a firm's performance if not handled properly. Borle et al (2005) find out that the reduction in product assortment actually reduces overall sales. With avalanche of products pouring into the market, it is now easier for the customers to shift to other brands at the slightest provocation. Evidence shows that product elimination provides a customer with a purchasing discontinuity that may allow them to migrate to other brands.

A research by Martin (2004) has increased our understanding of consumer responses to product discontinuance events, with particular attention given to emotional and behavioural responses. In product line contraction situations, consumers' reactions to the withdrawal of the discontinued alternative may influence future evaluation of and loyalty towards the brand. Martins (2004) found out that after discontinuance of a preferred product alternative, subjects in the study selected an alternative from a different product line more often than they did the original one, thus switching between brands. It would be helpful for marketers to understand the impact of marketing communications when discontinuing a product on consumers' brand loyalty.

Managing product recalls is a high responsibility that is often handled by the top management of an organisation. Studies have shown that in financial services the ability to fully eliminate a product is a difficult one because of contractual and legislative barriers (Harness and Marr, 2004; Harness and Marr, 2001). Harness, Marr, and Goy (1998) argue that without the knowledge of when or why a product may become sick, it is doubtful that proactive product management can be successfully accomplished. Product line rationalization is even a top priority for financial institutions that face the burden of excessive product proliferation. Thus, Argouslidis and Baltas (2007) put forward the concept of product formalization in the process and implementation of product elimination decision.

Although, little work has been done on product elimination in finance sector, a common thread runs through its process. Harness (2004) provides an overview of different stages involved in eliminating a product in banks, building societies and insurance organizations, and how the elimination process can help in achieving customer retention. Although, there 
are about ten alternative elimination strategies used by financial institutions, the predominant strategy is to eliminate a financial service from new customers, while leaving its existing users unconditionally unaffected (Argouslidis, 2004)

In a previous work, Harness (2000) groups into two the types of elimination existing in the financial services sector: partial elimination and full elimination. In the case of partial elimination, a product is removed from new sales but the existing customers still own the product, leaving support liability for the organization. In the case of full elimination, the product reaches a stage where support liability is ceased. In partial elimination, a firm may decide to make the product a closed issue so that no new customers could buy it, but keep the product open to the existing customers. Alternatively, the firm may make the product less attractive to the existing customers to encourage migration to new products. Another strategy is to withdraw the product from new sales, while the existing customers are forced to migrate to an alternative product. One other option is to withdraw certain product attributes, but leave its core functions intact. It could even be that the nature and functions of the product are changed but the brand name is reused. One further strategy is to sell the core product entirely to another organization.

Argouslidis (2007) provides both the practitioners and the scholars some understanding regarding the elimination decision process in financial institutions. His study was based on 20 in-depth interviews with top managers of some UK financial institutions, along with a mail survey of 112 specific elimination case histories from an equal number of UK banks, building societies and insurance companies. His findings reveal that the impact of a financial service's eventual elimination on the relationships of the company with its customers is rated as the most influential evaluation factor. Other influential evaluation factors are the impact on the public image of the institution and the impact on the sales and the profitability of other financial services in the range.

\section{Research Methodology}

This exploratory study is to find out the practice of product elimination in the Nigerian insurance industry. Factors normally considered before eliminating a product were also considered. The research design is the survey type which tries to unravel the experiences of the subject or variables under consideration without any attempt to control or manipulate them. Exploratory research design is normally used to study and gain insight into a situation that is not very clear and that has not attracted serious investigation (Asika, 2004). The simple random sampling method was used to select a sample of insurance companies. Although, there are seventy-one recapitalized insurance companies in Nigeria, some (being composite) still fall under the same ownership, use the same policy guidelines, and even occupy the same premises. The government had directed in 2005 that there should no longer be composite companies and that the existing ones should be split into life insurance companies and general insurance companies under separate management. We selected 40 insurance companies, 20 each from life insurance business and general insurance business respectively, and we tried to ensure that no two companies selected fall under the same ownership.

Questionnaire was used as our data gathering instrument, and a copy each was sent to a company. The questions were such that it would elicit information on the way products are being eliminated from the market, and factors that are normally considered before elimination decision is taken. Out of the 40 copies of questionnaire sent out, thirty-six were returned and thirty-four were correctly completed. These thirty-four serve as the basis for the following analysis.

From Table 1 in the Appendix, 70\% of the companies sampled agreed that product elimination in their organizations follows a formal procedure; $73 \%$ agreed that elimination decision is taken by the top management; and $68 \%$ agreed that customers are communicated when product is removed from the market. From Table 2, 79\% of the respondent companies have eliminated between 1 and 5 products from the market within the last five years. Table 3 shows that $44 \%$ of the companies would eliminate products from the market within 6 months of the management decision, and 33\% would do this between 7 and 12 months. Regarding partial elimination as shown on Table 4, 56\% of the companies use the strategy of making the product less attractive to existing customers to encourage migration to new product, while the most used strategy for full elimination as shown on Table 5 is to withdraw the product from new sales, and existing customers are forced to migrate to an alternate product.

As presented in Table 6, the most cited reasons for elimination are government policies and regulations $(85 \%)$, operational problems $(62 \%)$, poor profit performance $(50 \%)$, and decline in market potential $(47 \%)$. From Table 7 , the most cited problems encountered in the product elimination decision are maintaining customers' goodwill (59\%), and resistance by some staff in the organization (44\%). Thirty-eight percent of the respondents also cited lack of adequate information required for elimination decision, high product investment costs, and legal obstacles as some of the problems encountered. 


\subsection{Tests of Hypotheses}

The Kolmogorov-Smirnov method was used to test the formulated hypotheses. Like Chi-Square method, it is a goodness of fit test. It is appropriate here because the data being measured are ordinal. The Kolmogorov-smirnov test looks at the degree of agreement between the distribution of the observed values and some specified theoretical distribution (expected frequencies). The test focuses on the largest value of the deviations among observed and theoretical proportions. This test treats individual observation separately and thus, unlike $\chi^{2}$ test for one sample, need not lose information through the combining of categories. It is thus more powerful than $\chi^{2}$ test (Siegel, 1956) The Kolmogorov-Smirnov test is given as:

$$
\mathrm{D}=\max |\mathrm{Fo}(\mathrm{X})-\mathrm{Sn}(\mathrm{X})|
$$

where,

$\mathrm{F}$ is the number of observations,

$\mathrm{Fo}(\mathrm{X})$ is the specified (or theoretical) cumulative frequency distribution under Ho for any value of $\mathrm{X}$,

$\mathrm{Sn}(\mathrm{X})$ is the observed cumulative frequency distribution of a random sample of $\mathrm{N}$ observation for any value of $\mathrm{X}$.

The procedure is as follows: specify the null hypothesis; specify the level of significance; and state the decision rule.

The degree of freedom is measured against 5 percent level of significance. The critical value of D for sample size of $\mathrm{N}=34$ is 0.232 , as can be deduced from the Kolmogorov-Smirnov Table presented in the Appendix. The decision rule is that Ho will be rejected if the calculated D (i.e. $\mathrm{D}_{c a l}$ ) is greater than the tabulated $\mathrm{D}$ (i.e. $\mathrm{D}_{t a b}$ ) under the deviation level of 5 percent.

Hypothesis 1

$\mathrm{H}_{0}$ : Product elimination by the management of insurance companies in Nigeria does not follow a formal procedure.

$\mathrm{H}_{1}$ : Product elimination by the management of insurance companies in Nigeria follows a formal procedure.

Our sample size is $\mathrm{N}=34$. From the Kolmohorov-Smirnov Frequency Table for Hypothesis 1 shown in Appendix, the calculated D value is the point of greatest divergence between the cumulative observed and cumulative theoretical distributions, which is 0.306 . The tabulated $\mathrm{D}$ from the Kolmogorov-Smirnov Test Table at $\alpha=0.05$ for sample size $\mathrm{N}=34$ is 0.232 . The decision rule is that the null hypothesis will be rejected if the computed $\mathrm{D}$ is greater than the tabulated D. Here, $\mathrm{D}_{c a l}>\mathrm{D}_{t a b}$ (i.e. $0.306>0.232$ ), the null hypothesis is rejected. Therefore, we fail to reject the alternative hypothesis that product elimination by the management of insurance companies in Nigeria follows a formal procedure.

Hypothesis 2

$\mathrm{H}_{0}$ : Customers are not communicated when the insurers eliminate products from the market.

$\mathrm{H}_{1}$ : Customers are communicated when the insurers eliminate products from the market.

From Kolmogorov-Smirnov Frequency Table for Hypothesis 2 shown in the Appendix the calculated D is the point of greatest divergence between cumulative observed and theoretical distributions. In this case, it is 0.247 . At 5 percent level of significance, the tabulated value of $\mathrm{D}$, with the sample size of 34 is 0.232 , as shown in the table for Hypothesis 2 . The decision rule is that the null hypothesis will be rejected if the computed D is greater than the tabulated D. Here, $\mathrm{D}_{\text {cal }}>$ $\mathrm{D}_{t a b}$ (i.e. $0.247>0.232$ ), the null hypothesis is rejected. And we fail to reject the alternative hypothesis that states that customers are communicated when the insurers eliminate products from the market.

\section{Discussion and Conclusion}

In this paper, we have examined the procedure for product elimination in the Nigerian insurance market. The following are the findings from the paper:

- Product elimination follows a formal procedure in the insurance organisations, although the procedure may be relatively long. It may take up to six months in most organisations to reach elimination decision after identifying a weak product.

- While the decision to eliminate a product is generally taken at the top management level, responsibilities for eliminating a product are not assigned to any specific staff in most organisations.

- Customers are notified when a product is removed from the market by the majority of the organisations.

- Both partial and full elimination strategies are being used which include making the product available to existing customers only, and withdrawing the product from the market to force the existing customers to migrate to alternative products. This corroborates the earlier research by Harness (2000). 
- Government policies and regulations, and operational problems are the two most important reasons that organisations considered in reviewing a product for possible elimination, while poor profit performance and decline in market potentials are the third and fourth most cited reasons. These findings slightly differ from the results of a past research by Banville and Pletcher (1974) that indicated that profitability and financial variables are the most significant reasons in the elimination decision process.

- The most cited problem during elimination decision is maintaining customers' goodwill. This is in line with the earlier findings of Argouslidis (2007) that reveal that the relationship of the company with its customers is rated as the most influential evaluation factor. Other problems encountered by most organisations in product elimination activities include the resistance by some staff in the organisation, lack of accurate information, high product investment cost and legal obstacles.

\subsection{Recommendations}

One of the findings of this research is that the responsibilities for eliminating a product are not assigned to any specific staff in most organisations, which is a serious flaw in the elimination process. It is recommended that this important aspect of product management be assigned to specific and capable staff because poorly handled elimination may lead to purchase discontinuity.

One of the major problems encountered is the resistance of some staff to product elimination decision, which may suggest that they are not properly carried along in the elimination process. It is therefore recommended that in the organisations where there is the doctrine of shared vision, those in the position to know must be properly briefed about the management crucial decision in order to enlist their full cooperation.

Since, no known work has been done on this subject in the Nigerian insurance industry, these findings would form a platform on which both researchers and business managers can do further works. Future research could focus on the effects of product elimination on such variables as purchase discontinuity, customer's loyalty, company's sales and profitability etc.

\section{References}

Adeleye, A. S. (2003). Marketing principles and practice. (Revised), Concept Publications, Lagos. pp 180-181.

Alexander, R. S. (1964). The death and burial of sick products. Journal of Marketing, Vol. 28 pp.1-7. http://dx.doi.org/10.2307/1248881

Argouslidis, P. C. (2004). An empirical investigation into the alternative strategies to implement the elimination of financial services, Journal of World Business, Vol. 39, Iss. 4, pp.393-413. http://dx.doi.org/10.1016/j.jwb.2004.08.005

Argouslidis, P. C (2007). The evaluation stage in the service elimination decision-making process: evidence from the UK financial services sector. Journal of Services Marketing, Vol. 21, No. 2, 2007, pp. 122-136(15)

Argouslidis, P. C \& Baltas, G. (2007). Structure in product line management: the role of formalization in service elimination decisions. Journal of the Academy of Marketing Science. Vol. 35, No. 4. pp.471-491. http://dx.doi.org/10.1007/s11747-006-0004-2

Asika, N. (2004). Research methodology: a process approach $1^{\text {st }}$ ed. Mukugamu and Brothers Enterprise, Lagos. pp.20-23.

Assael, H. (1985)“Marketing management: strategy and action, Wadsworth, Boston, Massachussetts, USA, p.593

Avlonitis, G. J. (1983). The product elimination decision and strategies. Industrial Marketing Management, Vol. 12 pp.31-43. http://dx.doi.org/10.1016/0019-8501(83)90033-0

Avlonitis, G. J. (1985). Advisors and decision makers in product eliminations industrial. Industrial Marketing Management, Vol.14, pp.17-26. http://dx.doi.org/10.1016/0019-8501(85)90027-6

Avlonitis, G. J. (1990). Project dropstrat: product elimination and the product lifecycle concept, European Journal of Marketing, Vol. 24, No.9 pp.55-68. http://dx.doi.org/10.1108/EUM0000000000616

Avlonitis, G. J. (1993). Project dropstat: what factors do managers consider in deciding whether to drop a project? European Journal of Marketing, Vol. 27 pp.35-57. http://dx.doi.org/10.1108/03090569310038102

Banville, G. R. \& Pletcher, B. (1974).The product elimination function" Journal of Academy of Marketing Science, Vol. 2, No.3.(June), pp.432-446. http://dx.doi.org/10.1007/BF02729387 
Babington-Ashaye, F. (2009). The Nigerian insurance industry in 2009, [Online] Available: http://www.riskanalyst-ng.com/pdf/The_Nigerian_Insurance_Industry_in_2009-1.pdf

Borle, S., Boatwright, P., Kadane, J. B., Nunes, J.C. \& Shmueli, G. (2005). The effect of product assortment changes on customer retention, Marketing Science, Vol.24, No.4 (Fall), pp. 616-622. http://dx.doi.org/10.1287/mksc.1050.0121

Chilekezi, O. (2006). Marketing of non-life products. 2006 Nigerian Insurance Digest, pp. 97-100.

Daily Trust (2009) How insurance sector fared in 10 years [Online] Available: www.news.dailytrust.com

Eckles, W. R. (1971). Product line deletion and simplification: tough but necessary decisions, Business Horizons, Vol.14, Iss.5, (October), pp.71-74. http://dx.doi.org/10.1016/0007-6813(71)90092-9

Ghana Business News (2009). Nigeria insurance companies wary of underwriting group life business. Last updated on February 27, 2009.

Gounaris, S. P., Avlonitis, G. J. \& Papastathopoulou, P. G. (2006). Uncovering the keys to successful service elimination: Project ServDrop, Journal of Services Marketing, Vol. 20, No. 1, pp. 24-36. http://dx.doi.org/10.1108/08876040610646554

Harmon, R. R. \& Laird, G. L. (1997). Linking marketing strategy to customer value: implications for technology marketers, Kocaoglu, et al. (Eds), Innovation in Technology Management: The Key to Global Leadership, PICMET,July, 896-900, [Online] Available: http://www.cpd.ogi.edu/MST/capstone/Link

Harness, D. \& Marr, N. (2001). Product elimination: A barrier to successful financial service sector company mergers? Journal of Financial Services Marketing, Vol.6, No.1, pp. 67-76. http://dx.doi.org/10.1057/palgrave.fsm.4770041

Harness, D. R. (2003). The end stage of a financial service product, Journal of Financial Services Marketing, Vol. 7, pp. 220-229. http://dx.doi.org/10.1057/palgrave.fsm.4770087

Harness, D. R. \& Harness, T. (2000). Product elimination a relationship management tool. ANZMAC 2000 Visionary Marketing for the 21st Century: Facing the Challenge. [Online] Available: http://smib.vuw.ac,nz.8081/www/ANZMA2000/CDsite

Harness, D. R. (2004). Product elimination: a financial services model. International Journal of Bank Marketing, Vol.22, Iss. 3, pp. 161-179. http://dx.doi.org/10.1108/02652320410530296

Harness, D. R. \& Marr, N. E. (2004). A comparison of product elimination success factors in the UK banking, building society and insurance sectors, International Journal of Bank Marketing, Vol. 22 Iss. 2, pp.126 143. http://dx.doi.org/10.1108/02652320410521728

Harness, D. R., Marr, N. E. \& Goy, T. (1998). The identification of weak products revisited. Journal of Product and Brand Management. Vol. 7, issue 4, pp. 319-335. http://dx.doi.org/10.1108/10610429810229852

Hart, S. J. (1988). The causes of product elimination in British manufacturing companies, Journal of Marketing Management, Vol. 3 No.2, pp.328-43. http://dx.doi.org/10.1080/0267257X.1988.9964050

Hise, R. T. \& McGinnis, M. A. (1975). Product eliminations: practices policies and ethics. Business Horizons, Vol. 18 pp.25-32. http://dx.doi.org/10.1016/0007-6813(75)90049-X

Marketing Education Resource Center (2009). You can manage: the product service management function" LAP-PM-017-SP. [Online] Available: www.MBAResearch.org.

Martins, M. A (2004), Consumer responses to discontinuance of favourite products: an explanatory study. Advances in Consumer Research, Vol. 31, pp. 662-663

Mitchell, M. A., Taylor, R. D. \& Tanyel, F. (1995). Product elimination decision-making: after-the-fact. [Online] Available: www.sbaer.uca.edu/Research/sma/1995/pdf/08.pdf

Mowen, J. C. (1987). Consumer behavior, New York, Macmillan Publishing Company, pp.196-235.

Nigeria Investments. Com (2009) 28/8/09 Overview of the insurance industry in Nigeria August 9, 2009, [Online] Available: www.nigeriainvestments.com

Okehi, D. O. (2007). Strategic marketing of insurance products and service. The Nigerian Insurer. No. 14 (April). pp.4-17.

Rothe, J. T. (1970). The product elimination decision, MSU Business Topics, Vol. 18 (Autumn), pp. 45-52. 
Stewart, K. (1998). An exploration of customer exit in retail banking. International Journal of Banking International Journal of Bank Marketing .16(i), 6-14. http://dx.doi.org/10.1108/02652329810197735

Varadarajan, R., Defanti, M. P. \& Busch, P. S (2006). Brand portfolio, corporate image and reputation: managing brand deletions. Journal of the Academy of Marketing Science, Vol.34, No2 pp.195-205. http://dx.doi.org/10.1177/0092070305284988

Veena (2009). Insurance products, regulatory facade. The LCFAI University Journal of Insurance Law, Vol 12. No1, 2009 .pp.46-57

Vyas, N. M. (1993). Industrial product elimination decisions: some complex issues. European Journal of Marketing, Vol. 27 No.4, pp.58-76. http://dx.doi.org/10.1108/03090569310038111

Table1. Responses from the companies on their product elimination procedure $\mathrm{N}=34$

\begin{tabular}{|l|l|l|l|l|l|l|}
\hline Responses to Survey Questions & Agreed & $\begin{array}{l}\text { Perc- } \\
\text { entage }\end{array}$ & $\begin{array}{l}\text { Indiff- } \\
\text { erence }\end{array}$ & $\begin{array}{l}\text { Perc- } \\
\text { entage }\end{array}$ & $\begin{array}{l}\text { Disa- } \\
\text { greed }\end{array}$ & $\begin{array}{l}\text { Perc- } \\
\text { entage }\end{array}$ \\
\hline $\begin{array}{l}\text { There is a formal procedure for elimination } \\
\text { a product in this organization }\end{array}$ & 24 & $70 \%$ & 4 & $12 \%$ & 6 & $18 \%$ \\
\hline $\begin{array}{l}\text { Elimination activities tend to be long and } \\
\text { cumbersome }\end{array}$ & 17 & $50 \%$ & 5 & $15 \%$ & 12 & $35 \%$ \\
\hline $\begin{array}{l}\text { The decision to eliminate a product is } \\
\text { taken at the top management level }\end{array}$ & 25 & $73 \%$ & 6 & $18 \%$ & 3 & $9 \%$ \\
\hline $\begin{array}{l}\text { Elimination activities are initiated when } \\
\text { certain signals regarding a product appear }\end{array}$ & 31 & $91 \%$ & 1 & $3 \%$ & 2 & $6 \%$ \\
\hline $\begin{array}{l}\text { There is a laid down procedure for the } \\
\text { detection and evaluation of weak products }\end{array}$ & 23 & $68 \%$ & 7 & $20 \%$ & 4 & $12 \%$ \\
\hline $\begin{array}{l}\text { Responsibilities for eliminating a product } \\
\text { have been assigned to some staff }\end{array}$ & 13 & $38 \%$ & 3 & $9 \%$ & 18 & $53 \%$ \\
\hline $\begin{array}{l}\text { Customers are communicated when a } \\
\text { product is removed from the market }\end{array}$ & 23 & $68 \%$ & 4 & $12 \%$ & 7 & $20 \%$ \\
\hline
\end{tabular}

Source: Survey Report, 2010

Table 2. Number of products removed in the last three years $\mathrm{N}=34$

Source: Survey Report, 2010

\begin{tabular}{|l|l|l|}
\hline Number of products & $\begin{array}{l}\text { Companies } \\
\text { Citing }\end{array}$ & $\begin{array}{l}\text { Percentage } \\
\%\end{array}$ \\
\hline 0 & 6 & 18 \\
\hline $1-5$ & 27 & 79 \\
\hline $6-10$ & 1 & 3 \\
\hline
\end{tabular}

Table 3. Length of time it takes to eliminate a weak product $\mathrm{N}=34$

\begin{tabular}{|l|l|l|}
\hline Length of time & $\begin{array}{l}\text { Companies } \\
\text { Citing }\end{array}$ & $\begin{array}{l}\text { Percentage } \\
\%\end{array}$ \\
\hline No time frame & 2 & 6 \\
\hline Within 6 months & 15 & 44 \\
\hline $7-12$ months & 11 & 33 \\
\hline $13-18$ months & 2 & 6 \\
\hline 19-24 months & 4 & 1 \\
\hline
\end{tabular}

Source: Survey Report, 2010 
Table 4. Strategies used in partial elimination $\mathrm{N}=34$

\begin{tabular}{|l|l|l|}
\hline Strategies used in partial elimination & $\begin{array}{l}\text { Companies } \\
\text { Citing }\end{array}$ & $\begin{array}{l}\text { Percentage } \\
\%\end{array}$ \\
\hline $\begin{array}{l}\text { Remove the product from new sales, but made available } \\
\text { to existing customers }\end{array}$ & 15 & 44 \\
\hline $\begin{array}{l}\text { Remove the product from certain segments of customers, } \\
\text { but made available to other new and existing customers }\end{array}$ & 6 & 18 \\
\hline $\begin{array}{l}\text { Make the product less attractive to existing customers to } \\
\text { encourage migration to new product }\end{array}$ & 19 & 56 \\
\hline
\end{tabular}

Source: Survey Report, 2010

Table 5. Strategies used in full elimination $\mathrm{N}=34$

\begin{tabular}{|l|l|l|}
\hline Strategies used in full elimination & $\begin{array}{l}\text { Companies } \\
\text { Citing }\end{array}$ & $\begin{array}{l}\text { Percentage } \\
\%\end{array}$ \\
\hline $\begin{array}{l}\text { Withdraw the product from new sales, and existing } \\
\text { customers are forced to migrate to an alternate product }\end{array}$ & 16 & 47 \\
\hline $\begin{array}{l}\text { Withdraw the core product so that the organization is } \\
\text { relieved of any liability for service support for customers }\end{array}$ & 13 & 38 \\
\hline $\begin{array}{l}\text { Sell or transfer the core product along with its customers or } \\
\text { users to another organization }\end{array}$ & 12 & 35 \\
\hline
\end{tabular}

Source: Survey Report, 2010

Table 6. Circumstances that warrant a review of a product for possible elimination $\mathrm{N}=34$

\begin{tabular}{|l|l|l|}
\hline Circumstances & Companies citing & $\begin{array}{l}\text { Percentage } \\
\%\end{array}$ \\
\hline Government policies and regulations & 29 & 85 \\
\hline Operational problems & 21 & 62 \\
\hline Activities of the competitors & 13 & 38 \\
\hline Development of a new product & 8 & 23 \\
\hline Company's resources required elsewhere & 2 & 6 \\
\hline Decline in market potential & 16 & 47 \\
\hline Poor profit performance & 17 & 50 \\
\hline Poor quality or design & 13 & 38 \\
\hline Poor fit with company's capabilities or strategic plans & 11 & 32 \\
\hline Rationalization due to mergers and acquisitions & 12 & 35 \\
\hline Poor fit with company's image & 7 & 20 \\
\hline Parent company's decision and policies & 9 & 26 \\
\hline
\end{tabular}

Source: Survey Report, 2010

Table 7. Problems encountered in the product elimination decision $\mathrm{N}=34$

\begin{tabular}{|l|l|l|}
\hline Problems encountered & $\begin{array}{l}\text { Companies } \\
\text { citing }\end{array}$ & $\begin{array}{l}\text { Percentage } \\
\%\end{array}$ \\
\hline Lack of adequate information required for elimination decision & 13 & 38 \\
\hline Resistance by some staff in the organization & 15 & 44 \\
\hline Lack of interdepartmental cooperation during elimination stages & 10 & 29 \\
\hline High product investment costs & 13 & 38 \\
\hline Customer's resistance & 8 & 23 \\
\hline Finding a replacement product & 11 & 32 \\
\hline Maintaining customers' goodwill & 20 & 59 \\
\hline Legal obstacles & 13 & 38 \\
\hline
\end{tabular}

Source: Survey Report, 2010 
Table 8. Kolmogorov-Smirnov Frequency Table for Hypothesis 1

\begin{tabular}{|l|l|l|l|l|l|}
\hline \multicolumn{2}{|c|}{ Rank of view of respondents } \\
\hline $\begin{array}{l}\text { Strongly } \\
\text { agree }\end{array}$ & Agree & Indifferent & Disagree & $\begin{array}{l}\text { Strongly } \\
\text { disagree }\end{array}$ \\
\hline $\begin{array}{l}\mathrm{F}=\text { Number of } \\
\text { respondents according } \\
\text { to their views that } \\
\text { product elimination by } \\
\text { the Nigerian insurance } \\
\text { companies follows a } \\
\text { formal procedure }\end{array}$ & 12 & 12 & & & \\
\hline $\begin{array}{l}\mathrm{F}^{\mathrm{O}}(\mathrm{X})=\text { Theoretical } \\
\text { cumulative distribution } \\
\text { of choices under Ho }\end{array}$ & 0.200 & 0.400 & 0.600 & 0.800 & 1 \\
\hline $\begin{array}{l}\mathrm{F}_{\mathrm{o}}(\mathrm{X})=\text { Cumulative } \\
\text { distribution of observed } \\
\text { choices under Ho }\end{array}$ & $0 . .353$ & 0.706 & 0.835 & $0 . .970$ & 1 \\
\hline $\begin{array}{l}\text { Fo(X) - Sn(X) } \\
\text { Report, 2010 }\end{array}$ & 0.153 & 0.306 & 0.253 & 0.170 & 0 \\
\hline
\end{tabular}

Source: Survey Report, 2010

Table 9. Kolmogorov-Smirnov Frequency Table for Hypothesis 2

\begin{tabular}{|l|l|l|l|l|l|}
\hline \multicolumn{2}{|l|}{ Rank of view of respondents } \\
\hline $\begin{array}{l}\text { Strongly } \\
\text { agree }\end{array}$ & Agree & Indifferent & Disagree & $\begin{array}{l}\text { Strongly } \\
\text { disagree }\end{array}$ \\
\hline $\begin{array}{l}\text { F Number of } \\
\text { to their views that } \\
\text { customers are not } \\
\text { communicated when the } \\
\text { insurers eliminate } \\
\text { products from the } \\
\text { market }\end{array}$ & 7 & & & & \\
\hline $\begin{array}{l}\mathrm{F}^{\mathrm{O}}(\mathrm{X})=\text { Theoretical } \\
\text { cumulative distribution } \\
\text { of choices under Ho }\end{array}$ & 0.200 & 0.400 & 0.600 & 0.800 & 1 \\
\hline $\begin{array}{l}\mathrm{F}_{\mathrm{o}}(\mathrm{X})=\text { Cumulative } \\
\text { distribution of observed } \\
\text { choices under Ho }\end{array}$ & 0.206 & 0.647 & 0.823 & $0 . .970$ & 1 \\
\hline \begin{tabular}{l} 
Fo(X) - Sn(X) \\
\hline
\end{tabular} & 0.006 & 0.247 & 0.223 & 0.170 & 0 \\
\hline
\end{tabular}

Source: Survey Report, 2010 